\title{
Porous Structure of Municipal Solid Waste Incineration Bottom Ash in Initial Stage of Landfill
}

\author{
Shogo Sakita, Jun Nishimoto, Kazuyuki Nishimura \\ Department of Environmental Sciences, Prefectural University of Hiroshima, Shobara City, Japan \\ Email:sakita@pu-hiroshima.ac.jp
}

How to cite this paper: Sakita, S., Nishimoto, J. and Nishimura, K. (2017) Porous Structure of Municipal Solid Waste Incineration Bottom Ash in Initial Stage of Landfill. Journal of Geoscience and Environment Protection, 5, 9-20.

https://doi.org/10.4236/gep.2017.59002

Received: July 16, 2017

Accepted: August 20, 2017

Published: August 23, 2017

Copyright (c) 2017 by authors and Scientific Research Publishing Inc. This work is licensed under the Creative Commons Attribution International License (CC BY 4.0).

http://creativecommons.org/licenses/by/4.0/

\begin{abstract}
For quantitative estimation of the intra-layer porous structure in the initial stage of landfill formation with municipal solid waste incineration (MSWI) bottom ash, the water absorption of individual MSWI bottom ash particles was measured under still-water, degassed, and agitated conditions. The ratio of the water absorption rate found for the still-water procedure to the effective absorption capacity which was the one under degassing was $35.2 \%$. In the water flow experiment of a column filled with MSWI bottom ash, the true density of the bottom ash was higher after water flow than before, which indicated that dissolution of the soluble components of the bottom ash particle surfaces resulted in a loss of apparent particle volume that more than offset the accompanying weight loss. The volume-based water absorption rate found for the bottom ash particles following $50 \mathrm{~mL} / \mathrm{h}$ water flow through the column, as a ratio to the effective absorption capacity was about $51.8 \%$ of the effective absorption capacity. In a landfill layer comprised of MSWI bottom ash, it was suggested that some regions of the ash particle interiors underwent almost no contact with water.
\end{abstract}

\section{Keywords}

Municipal Solid Waste Incineration (MSWI) Bottom Ash, Water Absorption, Porous Structure, Landfill

\section{Introduction}

In Japan, approximately $80 \%$ of municipal solid waste is incinerated and its importance is growing, as finding new sites for final disposal has become more and more difficult, particularly in urban areas. Municipal solid waste incineration (MSWI) residues constitute the main material in final waste disposal, accounting 
for about $74 \%$ of all landfilled waste [1].

Internal stabilization of landfill layers formed by waste materials begins with component washout by rainwater. MSWI residues are similar in composition to the raw material of cement [2] [3], and in a landfill layer may be expected to harden and solidify over time as its components undergo hydration [4] [5]. Incineration residues are high in calcium $(\mathrm{Ca})$ content and may be expected to undergo mineralization and changes in physical microstructure, with carbonation by carbon dioxide $\left(\mathrm{CO}_{2}\right)$ generating mainly such minerals as calcite $\left(\mathrm{CaCO}_{3}\right)$, ettringite $\left(3 \mathrm{CaOAl}_{2} \mathrm{O}_{3} \mathrm{CaSO}_{4} \cdot 32 \mathrm{H}_{2} \mathrm{O}\right)$, gypsum $\left(\mathrm{CaSO}_{4} \cdot 2 \mathrm{H}_{2} \mathrm{O}\right)$, and anhydrite $\left(\mathrm{CaSO}_{4}\right)$ [6]-[11]. These changes are known to result in the gradual formation of water pathways within the landfill layer [12] [13] [14]. Rosqvist and Destouni performed tracer experiments in undisturbed landfill waste samples and showed that approximately $55 \%-70 \%$ of the infiltrating water followed preferential flow paths [15]. This tends to prevent homogeneous washing of landfilled waste components by rainwater and hinders external release of gases generated within the landfill layer [16].

MSWI bottom ash particles occur in many different derivations, shapes, and sizes. They are porous, with a small pore size and large pore density, and exhibit capillarity that becomes high with decreasing pore size [12]. Because the MSWI bottom ash particle surface is generally hydrophobic, however, it is believed that water either does not penetrate to the particle interior (and thus is not absorbed), or penetrates only over an extremely long time span. Stabilization of the particle interior may therefore lag far behind the particle surface. At present, much remains unknown in regard to water pathway formation in MSWI bottom ash landfills and the water absorption of the MSWI bottom ash particles themselves, and the effects on leachate properties and stabilization of landfilled wastes.

In this study, for quantitative estimation of the intra-layer porous structure in the initial stage of landfill formation with MSWI bottom ash, the water absorption of individual MSWI bottom ash particles were measured and then investigated the flow of water through a column filled with the MSWI bottom ash as a simulated landfill layer, and its effects on the intra-layer porous structure accompanying the elution of its soluble components.

\section{Materials and Methods}

\subsection{Samples}

The samples used in this study were composed of water-quenched MSWI bottom ash generated in a semi-continuous stoker furnace with unburned materials and incombustible parts like metals removed as much as possible. The particle size distribution is shown in Figure 1, and the true density measured by a pycnometer method was $2.54 \mathrm{~kg} / \mathrm{cm}^{3}$. The contents of $\mathrm{Pb}, \mathrm{Zn}, \mathrm{Cd}, \mathrm{Cr}, \mathrm{Cu}, \mathrm{Na}, \mathrm{K}$, and Ca were analyzed by inductively coupled plasma atomic emission spectroscopy (SPS7800, Seiko Instruments Inc.) after digestion by nitric and perchloric acid 


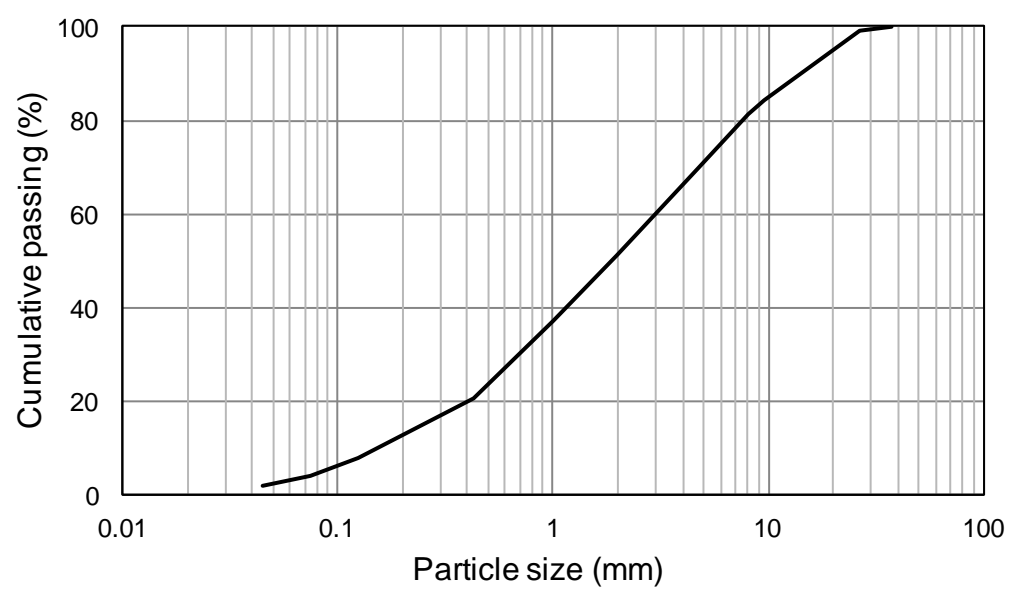

Figure 1. Particle-size distribution of the MSWI bottom ash sample.

followed by filtration. The samples were also submitted to Japan Leaching Test No. 13 (JLT13), which is a standard leaching test for waste in Japan in which a suspension with a liquid/solid weight ratio (L/S) of 10 was shaken for 6 hours and then filtered using a $1 \mu \mathrm{m}$ glass filter, followed by filtrate measurement and analysis for $\mathrm{pH}$ (HM-50G, TOA DKK Corporation), electrical conductivity (EC; CM-30G, TOA DKK Corporation), P-alkalinity, and each concentration of $\mathrm{Pb}$, $\mathrm{Zn}, \mathrm{Cd}$, Total $\mathrm{Cr}$ (T-Cr), $\mathrm{Cu}, \mathrm{Na}, \mathrm{K}, \mathrm{Ca}$, and $\mathrm{Cl}^{-}$. Analysis for $\mathrm{Cl}^{-}$was performed by the Mohr method. The content analysis and JLT13 results are shown in Table 1.

\subsection{Bottom Ash Particle Water Absorption}

MSWI bottom ash particles are porous, with the pores varying in size. In this experiment in order to estimate void structure, water absorption rate (\%) of MSWI bottom ash particles, which is defined as the rate (\%) of the water content of ash particles after absorption of pure water for a specified time and surface drying to the dry weight of them. Mercury porosimeter method and nitrogengas adsorption isotherms are commonly used to investigate the void volume and void distribution in porous bodies, but here we applied the coarse-aggregate water absorption rate measurement method specified in the Japanese Industrial Standards (JIS A1110).

Figure 2 schematically shows the three states of water absorption by bottom ash particles. In the wet state, the absorbed water extends to the particle surface. In the dry-surface state, the water has been removed from the surface of the wet-state particle. In the absolute-dry state, the dry-surface state sample has been further dried by heating at $110^{\circ} \mathrm{C}$ until the weight of the particle becomes constant.

The water absorption rate of MSWI bottom ash was measured by the following three procedures, using samples with particle sizes $d \geq 2 \mathrm{~mm}$.

a) Still-water absorption: $50 \mathrm{~g}$ of the sample and $500 \mathrm{~mL}$ of pure water were placed in a $500 \mathrm{~mL}$ beaker and water absorption was allowed to proceed while 
Table 1. Sample content and JLT13 leachate concentration.

\begin{tabular}{cccc}
\hline & content $(\mathrm{mg} / \mathrm{kg})$ & JLT 13 & JLT 13 standard values \\
\hline $\mathrm{pH}$ & - & 11.2 & - \\
$\mathrm{EC}$ & - & $560 \mathrm{mS} / \mathrm{m}$ & - \\
$\mathrm{K}$ & 25,100 & $7668 \mathrm{mg} / \mathrm{L}$ & - \\
$\mathrm{Ca}$ & 13,990 & $53.8 \mathrm{mg} / \mathrm{L}$ & - \\
$\mathrm{Cl}-$ & 12,005 & $365.8 \mathrm{mg} / \mathrm{L}$ & $0.3 \mathrm{mg} / \mathrm{L}$ \\
$\mathrm{Pb}$ & 54.6 & $0.148 \mathrm{mg} / \mathrm{L}$ & - \\
$\mathrm{Zn}$ & 175 & $0.042 \mathrm{mg} / \mathrm{L}$ & $0.3 \mathrm{mg} / \mathrm{L}$ \\
$\mathrm{Cd}$ & 3.71 & $0.005 \mathrm{mg} / \mathrm{L}$ & $1.5 \mathrm{mg} / \mathrm{L} \mathrm{as} \mathrm{Cr}(\mathrm{VI})$ \\
$\mathrm{T}-\mathrm{Cr}$ & 1110 & $0.79 \mathrm{mg} / \mathrm{L}$ & - \\
$\mathrm{Cu}$ & 156 & $4.74 \mathrm{mg} / \mathrm{L}$ & \\
\hline
\end{tabular}

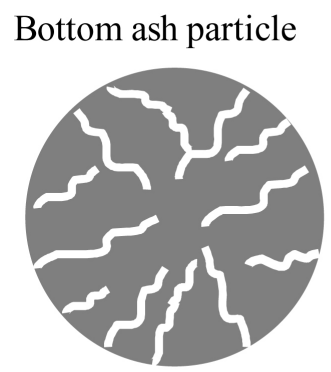

(a)

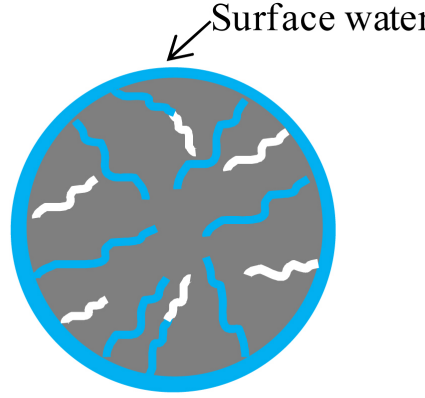

(b)

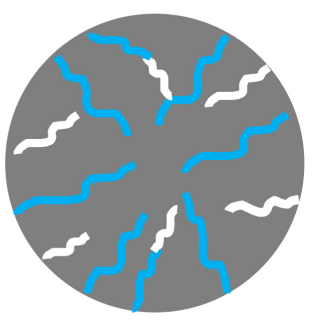

(c)

Figure 2. Water absorption states of bottom ash particles in (a) absolute-dry, (b) postwater absorption wet, and (c) dry-surface states.

standing for 72 hours.

b) Degassed absorption: the sample and pure water were placed in a glass beaker as in procedure a), the beaker was then placed in glass desiccator attached to vacuum pump, and water absorption was allowed to proceed for 72 hours while degassing.

c) Agitated absorption: the sample and pure water were placed in a glass beaker as in procedure a) and permitted to absorb water for 72 hours under agitation by a suspended stirrer (SM-102, As One Corp.) rotating at 100, 200, or $300 \mathrm{rpm}$.

For each experiment, a preliminary trial was first performed to confirm attainment of a constant weight within the specified period. Each procedure was followed by filtration through $1.0 \mu \mathrm{m}$ membrane filter, measurement of the wet-particle weight $m_{2}(\mathrm{~kg})$ of the sample (with water present both on the surface and within the particles), oven-drying at $110^{\circ} \mathrm{C}$ for 24 hours, and air cooling followed by measurement of the resulting dry weight $m_{s}(\mathrm{~kg})$. The sample was then immediately immersed in $500 \mathrm{~mL}$ of pure water, quickly followed by filtering through a $1.0 \mu \mathrm{m}$ membrane filter and measurement of the resulting wetsurface weight $m_{3}(\mathrm{~kg})$ of the sample (with water present only on the particle 
surface). The water absorption rate was calculated as the weight-based rate $P$ (w/w \%) and as the volume-based rate $P^{\prime}(\mathrm{v} / \mathrm{v} \%)$ using Equations (1) and (2), respectively. Each procedure was implemented with 50 bottom ash particles.

$$
\begin{gathered}
P=\frac{m_{1}-m_{s}}{m_{s}} \times 100(\%) \\
P^{\prime}=\frac{\rho_{s}}{\rho_{w}} P(\%)
\end{gathered}
$$

Here, $P$ is the weight-based MSWI bottom ash particle water absorption rate (w/w \%), $P^{\prime}$ is the volume-based incineration ash particle water absorption rate $(\mathrm{v} / \mathrm{v} \%), m_{\mathrm{s}}$ is the weight $(\mathrm{g})$ of the sample in the absolute-dry state, $m_{1}$ is the weight $(\mathrm{g})$ of the sample in the dry-surface state, $\rho_{\mathrm{s}}$ is the true density of MSWI bottom ash $\left(\mathrm{g} / \mathrm{cm}^{3}\right)$, and $\rho_{\mathrm{w}}$ is the density $\left(\mathrm{g} / \mathrm{cm}^{3}\right)$ of pure water at room temperature $\left(20^{\circ} \mathrm{C}\right)$.

\subsection{Water Flow Experiment through a Column Filled with the MSWI Bottom Ash}

An acrylic column was filled with MSWI bottom ash to simulate an actual landfill layer, water was flowed into the column, and the bottom ash was investigated for macro changes in intra-layer porous structure resulting from elution of its soluble components in the water flow. As shown schematically in Figure 3, the column was $80 \mathrm{~mm}$ in inner diameter and $300 \mathrm{~mm}$ in height. The bottom ash particle size was $d<8 \mathrm{~mm}$, and the bulk density of $1.2 \mathrm{~g} / \mathrm{cm}^{3}$ simulated that of a landfill. The packing height was $250 \mathrm{~mm}$ (packing weight: $1507 \mathrm{~g}$ ). The direction of water (pure water) flow was upward from the bottom to the top of the column by a tubing pump (MasterFlex L/S 07528-30, Cole-Parmer International) to avoid formation of unsaturated zones and preferential flow pathways [17]. The

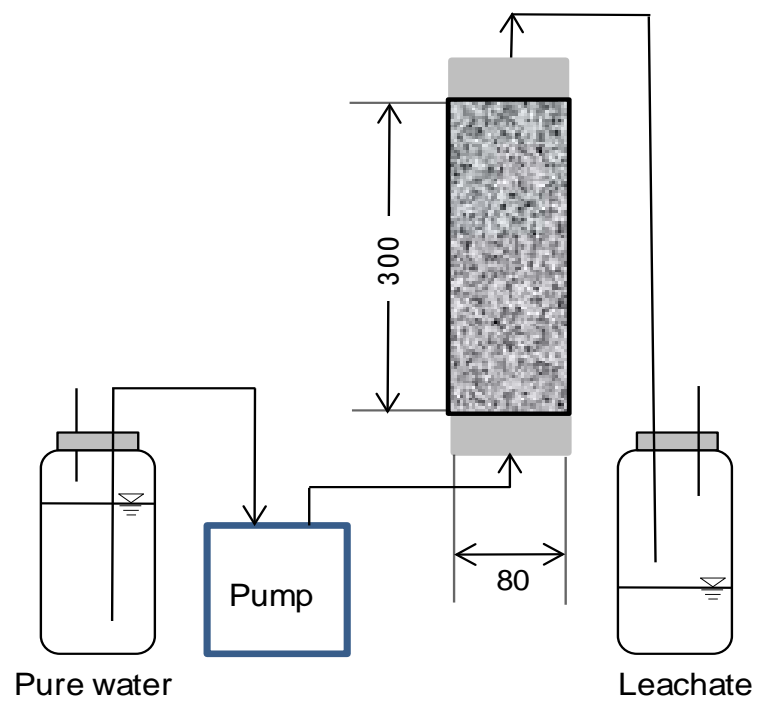

Unit: $\mathrm{mm}$

Figure 3. Schematic of column water flow experiment. 
water flow rate of 50,110 , or $320 \mathrm{~mL} / \mathrm{h}$ at the start of the experiment. EC of leachate was measured periodically until the L/S ratio reached 10 . When the EC reached almost zero, inflowed pure water was changed to a sodium chloride $(\mathrm{NaCl})$ solution $(5000 \mathrm{mg} / \mathrm{L})$ to determine the water retention time in the column by tracer measurement. Although $\mathrm{Cl}^{-}$is generally not appropriate as a tracer with MSWI bottom ash samples such as those of the present study because of their high inorganic contents, the $\mathrm{NaCl}$ solution was used as a tracer in this case because it was flowed after EC reached very low. The leachates were periodically sampled using a fraction collector (CHF 121SA, Advantec Toyo Corp.). After filtration through $1.0 \mu \mathrm{m}$ membrane filter, $\mathrm{pH}, \mathrm{EC}$, evaporation residue, $\mathrm{Cl}, \mathrm{Ca}, \mathrm{K}, \mathrm{Na}, \mathrm{Cr}, \mathrm{Cu}, \mathrm{Zn}, \mathrm{Cd}$, and $\mathrm{Pb}$ concentrations of each leachate were measured.

After completion of water flow, the bottom ash particles were removed from the column, their true density was measured using a pycnometer, and the porosity of the waste filled in the column was calculated using Equation (3). The water absorption rate of the 50 bottom ash particles was measured after the $50 \mathrm{~mL} / \mathrm{h}$ flow procedure.

$$
\varepsilon_{i}=1-\frac{m_{i}}{\rho_{s} V}
$$

Here, $\varepsilon_{i}$ is the porosity, $m_{i}$ is the filled sample weight $(\mathrm{g}), \rho_{s}$ is the true density of the sample $\left(\mathrm{g} / \mathrm{cm}^{3}\right)$, and $V$ is the packing volume $\left(\mathrm{cm}^{3}\right)$.

\section{Results and Discussion}

\subsection{Water Absorption of Bottom Ash Particles}

Figure 4 shows the water absorption rate ((a) weight-based, (b) volume-based) found for the bottom ash particles in the still-water, degassed, and agitated procedures. Volume-based water absorption rate was calculated from weight-based one using Equation (2). The measured values ranged from 0.31 to 2.08 times the

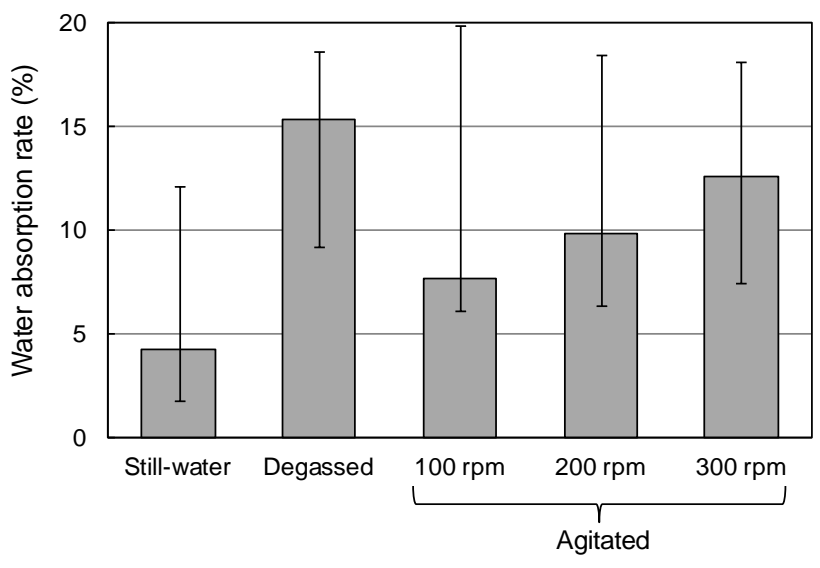

(a)

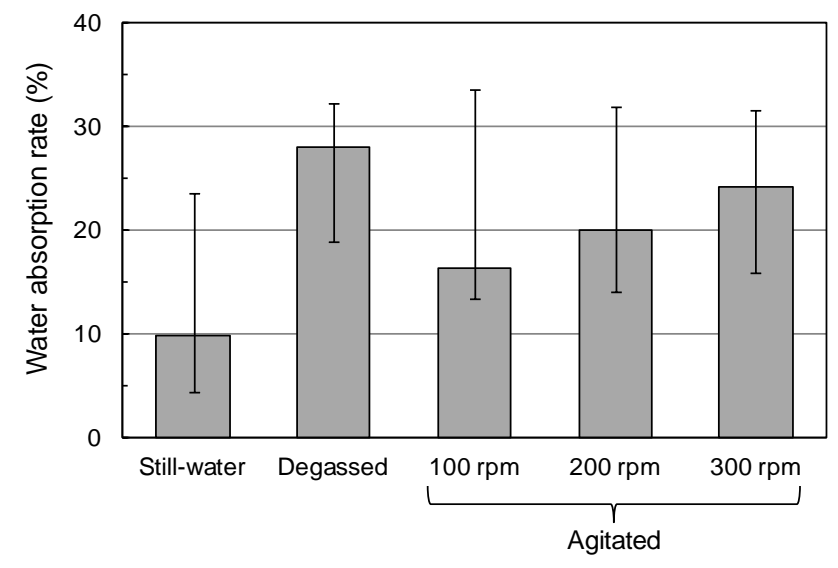

(b)

Figure 4. Water absorption rates for bottom ash particles (number of MSWI bottom ash particles = 50). (a) Weight-based, (b) Volume-based. 
mean was higher than those found for the other procedures. The measured values ranged from 0.31 to 2.08 times the mean values, due to the particle heterogeneity. The water absorption rate under degassing was higher than those found for the other procedures, and apparently represents the maximum attainable ratio for such particles. It is therefore referred to as the "effective absorption capacity" in this study. The ratio of the water absorption rate found for the stillwater procedure to the effective absorption capacity was $35.2 \%$ in the weightbased, which was the lowest found in any of the procedures and showed that only about $1 / 3$ of the effective absorption capacity was utilized in still-water. Under agitation, the water absorption rate was $58.5 \%$ at $100 \mathrm{rpm}$ and $71.4 \%$ at $200 \mathrm{rpm}$ as a result of volume-based. The water absorption rate thus increased with stirring speed, and at $300 \mathrm{rpm}$ reached $86.4 \%$ of the effective absorption capacity.

In actual landfills, the coefficient of permeability in layers composed primarily of MSWI bottom ash is low, and the results of this experiment indicate that in such regions the water flowing between bottom ash particles does not completely fill the particle interiors, with about two-thirds of the pores undergoing little or no water washing.

\subsection{MSWI Bottom Ash Packed Column Water Flow}

Figure 5 shows the relation between the $\mathrm{L} / \mathrm{S}$ ratio and the leachate $\mathrm{pH}, \mathrm{EC}, \mathrm{Cl}^{-}$,
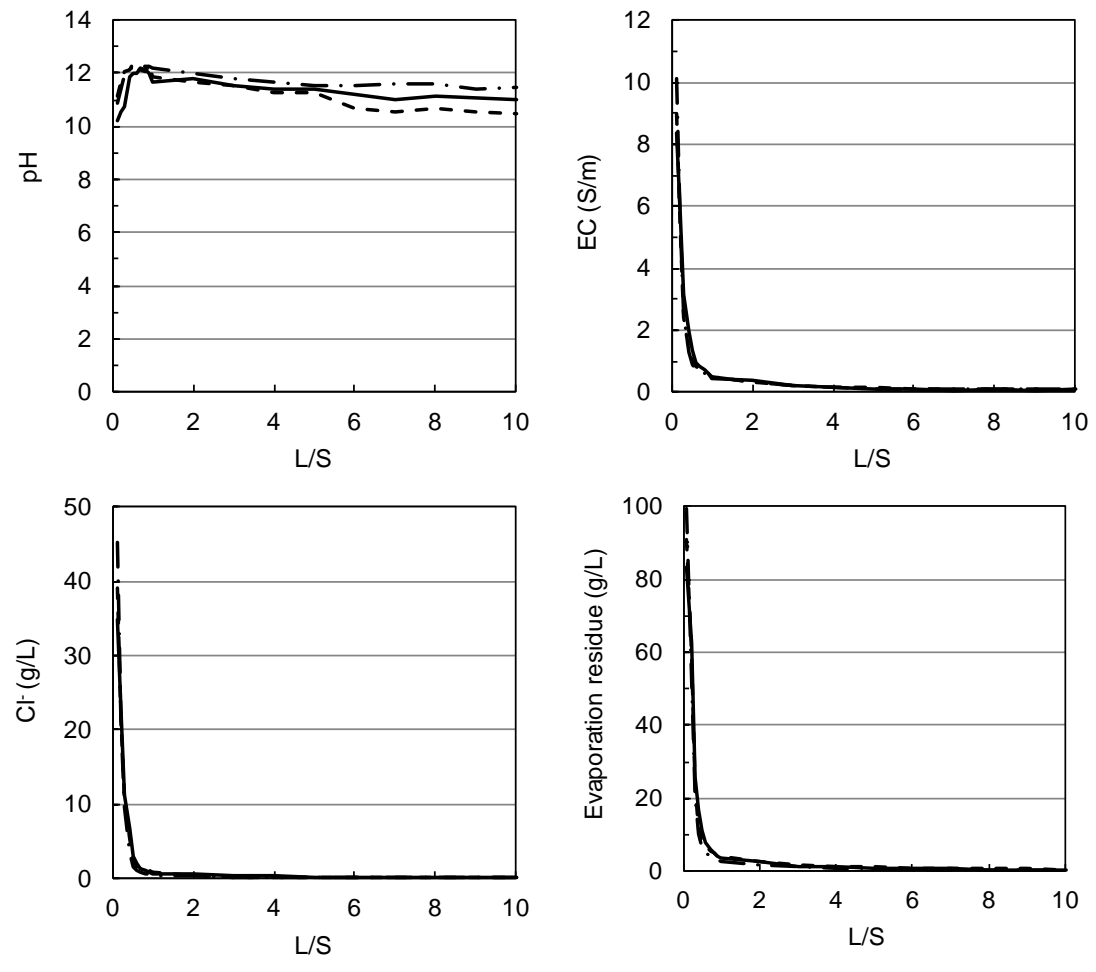

$50 \mathrm{~mL} / \mathrm{h}$

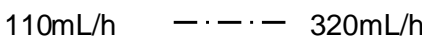

Figure 5. Relation between $\mathrm{L} / \mathrm{S}$ ratio and $\mathrm{pH}, \mathrm{EC}, \mathrm{Cl}^{-}$, and evaporation residue concentration, under pure water flow. 
and evaporation residue concentration under flow of pure water into a column filled with MSWI bottom ash. The $\mathrm{EC}, \mathrm{Cl}^{-}$, and evaporation residue concentration fell sharply as the L/S ratio rose to about 3 , indicating rapid elution of readily soluble components of the bottom ash. The $\mathrm{pH}$ rose just after water flow and then declined to about 11, but no large change was observed under the flow rates used in this study. The cumulative evaporation residues at L/S ratios of up to 10 were $3.89,4.41$, and $4.82 \mathrm{~g} / \mathrm{kg}$-dry bottom ash under water flow rates of 50 , 110 and $320 \mathrm{~mL} / \mathrm{h}$, respectively, thus showing increasing elution of the bottom ash particles and their soluble components with increasing water flow rate.

Table 2 shows the true density found for the bottom ash particles and the porosity of the packed bed in the column before and after water flow, as calculated by Equation (3). The true density was higher after water flow than before, which indicates that dissolution of the soluble components of the bottom ash particle surfaces resulted in a loss of apparent particle volume that more than offset the accompanying weight loss. The decrease in true density after water flow increased with the flow rate, with a similar trend found for the cumulative evaporation residue. The porosity of the packed bed in the column was $22 \%-44 \%$ higher after water flow than before, which also indicates that the inter-particle void fraction increased with decreasing particle volume.

Figure 6 shows the relation between the L/S ratio and the $\mathrm{Cl}^{-}$concentration in

Table 2. True density of bottom ash particles and porosity of packed bed, before and after water flow.

\begin{tabular}{ccccc}
\hline \multirow{2}{*}{$\begin{array}{c}\text { Initial flow rate } \\
(\mathrm{mL} / \mathrm{h})\end{array}$} & \multicolumn{2}{c}{ True density $\left(\mathrm{g} / \mathrm{cm}^{3}\right)$} & \multicolumn{2}{c}{ Porosity $(-)$} \\
\cline { 2 - 5 } & $\begin{array}{c}\text { Before } \\
\text { water flow }\end{array}$ & $\begin{array}{c}\text { After } \\
\text { water flow }\end{array}$ & $\begin{array}{c}\text { Before } \\
\text { water flow }\end{array}$ & $\begin{array}{c}\text { After } \\
\text { water flow }\end{array}$ \\
\hline 50 & & 2.494 & & 0.442 \\
110 & 1.878 & 2.292 & 0.361 & 0.476 \\
320 & & 2.152 & & 0.519 \\
\hline
\end{tabular}

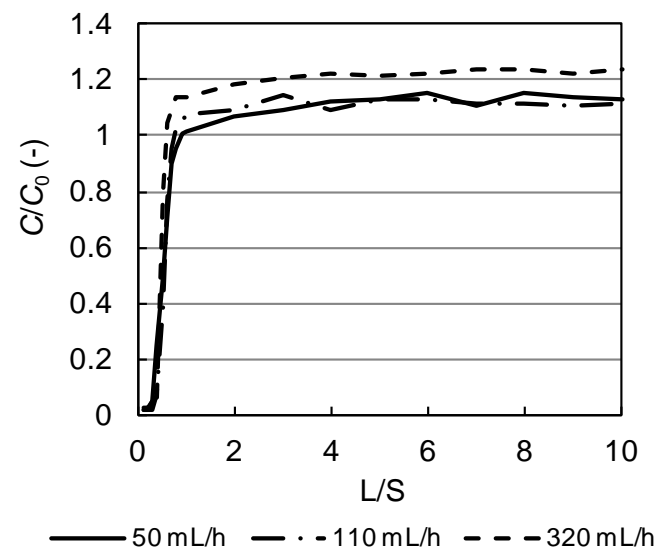

Figure 6. Relation between $C / C_{0}$ and $\mathrm{L} / \mathrm{S}$ ratio $(C$ : $\mathrm{Cl}^{-}$concentration in column leachate; $C_{0}: \mathrm{Cl}^{-}$concentration in column feed). 
the leachate under injection of the $\mathrm{NaCl}$ solution in the tracer experiment. The vertical axis represents $C / C_{0}$, where $C$ is the $\mathrm{Cl}^{-}$concentration in the column leachate and $C_{0}$ is the $\mathrm{Cl}^{-}$concentration in the inflow solution. The rise in outflow $\mathrm{Cl}^{-}$concentration to a value slightly higher than that for the feed $\mathrm{Cl}^{-}$concentration indicates that a small amount of $\mathrm{Cl}^{-}$remained present in the column after pure water flow. The rise in $\mathrm{Cl}^{-}$concentration showed a tendency to occur earlier at higher flow rates. The retention time at 50,110 , and $320 \mathrm{~mL} / \mathrm{h}$, as calculated from the effluent discharge during pure water flow and after breakthrough following the change to the $\mathrm{NaCl}$ solution divided by the time, were $8.19,4.05$, and $1.19 \mathrm{~h}$, respectively, just after pure water flow, and 6.20, 2.81, and $0.96 \mathrm{~h}$, respectively, after $\mathrm{NaCl}$ solution flow breakthrough. The shorter retention time following $\mathrm{NaCl}$ solution flow breakthrough are presumably attributable to elution of the readily soluble components during pure water flow, resulting in an increased porosity of the packed bed in the column (Table 2), thus facilitating water flow.

Figure 7 shows the volume-based water absorption rate found for the 50 MSWI bottom ash particles following $50 \mathrm{~mL} / \mathrm{h}$ water flow through the column, as a ratio to the effective absorption capacity. Also shown are the ratios found for the still-water and agitated absorption (See 2.2). Despite the water-saturated state in the column flow experiment, the water absorption rate was only about $51.8 \%$ of the effective absorption capacity, which indicates that the particle interiors remained unsaturated in the saturated inter-particle porous environment.

In summary, the results indicate that in a landfill layer comprised of MSWI bottom ash, some regions of the ash particle interiors undergo almost no contact with water. This in turn implies that a landfill meeting the leachate standards for its quality may actually retain harmful or hazardous materials.

\section{Conclusions}

The water absorption rate of MSWI bottom ash was measured under still-water,

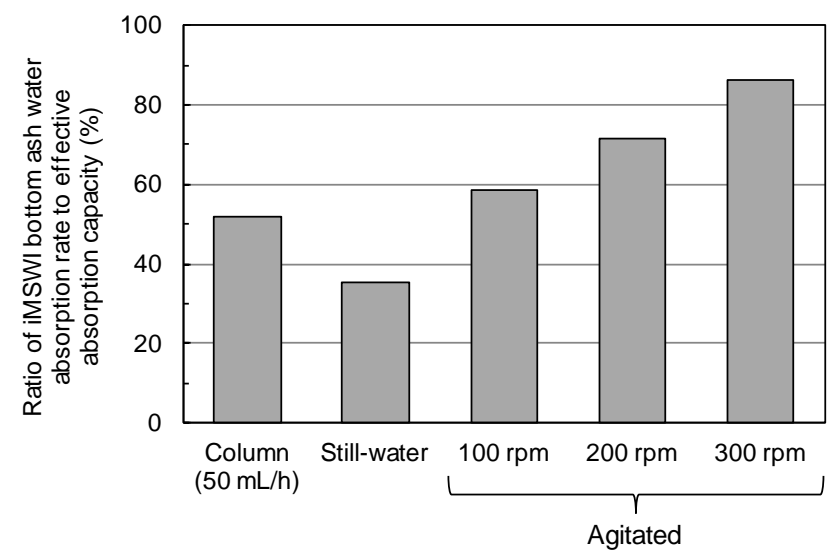

Figure 7. Ratio of MSWI bottom ash water absorption rate to effective absorption capacity, in column with flow rate of $50 \mathrm{~mL} / \mathrm{h}$, the still-water and agitated absorption. 
degassed, and agitated conditions. The ratio of the water absorption rate found for the still-water procedure to the effective absorption capacity was $35.2 \%$. Under agitation, the water absorption rate increased with stirring speed, and at 300 rpm reached $86.4 \%$ of the effective absorption capacity. In actual landfills, the coefficient of permeability in layers composed primarily of MSWI bottom ash is low, and the results indicate that in such regions the water flowing between bottom ash particles does not completely fill the particle interiors, with about twothirds of the pores undergoing little or no water washing.

In the water flow experiment of column filled with MSWI bottom ash, the true density of the bottom ash was higher after water flow than before, which indicates that dissolution of the soluble components of the bottom ash particle surfaces resulted in a loss of apparent particle volume that more than offset the accompanying weight loss. The porosity of the packed bed in the column was $22 \%-44 \%$ higher after water flow than before, which also indicates that the inter-particle void fraction increased with decreasing particle volume.

In the tracer experiment with $\mathrm{NaCl}$ solution, the retention time at each water flow rate was decreased. The shorter retention time following $\mathrm{NaCl}$ solution flow breakthrough was presumably attributable to elution of the readily soluble components during pure water flow, resulting in an increased porosity of the packed bed in the column, thus facilitating water flow.

The volume-based water absorption rate found for the bottom ash particles following $50 \mathrm{~mL} / \mathrm{h}$ water flow through the column, as a ratio to the effective absorption capacity was only about $51.8 \%$ of the effective absorption capacity. This indicates that the particle interiors remained unsaturated in the saturated inter-particle porous environment.

Further investigation will be necessary on long-term hardening and solidification of the landfill layer, allowing uniformwater and gas transport inside and outside the landfill layer.

\section{Acknowledgements}

This study was supported by Japan Society for the Promotion of Science (JSPS), Grant Number 16K06555.

\section{References}

[1] Japan Ministry of the Environment (2016) 2015 Annual Report on Waste Management in Japan (in Japanese). Japan Ministry of the Environment, Tokyo.

[2] Lam, C.H.K., Barford, J.P. and McKay, G. (2011) Utilization of Municipal Solid Waste Incineration Ash in Portland Cement Clinker. Clean Technologies and Environmental Policy, 13, 607-615.

https://link.springer.com/article/10.1007/s10098-011-0367-z\#aboutcontent https://doi.org/10.1007/s10098-011-0367-z

[3] Kim, H.K., Jeon, J.H. and Lee, H.K. (2012) Flow, Water Absorption, and Mechanical Characteristics of Normal- and High-Strength Mortar Incorporating Fine Bottom Ash Aggregates. Construction and Building Materials, 26, 249-256. 
https://doi.org/10.1016/j.conbuildmat.2011.06.019

[4] Speiser, C., Baumann, T. and Niessner, R. (2001) Characterization of Municipal Solid Waste Incineration (MSWI) Bottom Ash by Scanning Electron Microscopy and Quantitative Energy Dispersive X-Ray Microanalysis (SEM/EDX). Fresenius' Journal of Analytical Chemistry, 370, 752-759.

https://doi.org/10.1007/s002160000659

[5] Sabbas, T.A., Polettini, R., Pomi, T., Astrup, O., Hjelmar, P., Mostbauer, G., Cappai, G., Magel, S., Salhofer, C., Speiser, S., Heuss-Assbichler, R., Klein, P. and Lechner, P. (2003) Management of Municipal Solid Waste Incineration Residues. Waste Management, 23, 61-88. https://doi.org/10.1016/S0956-053X(02)00161-7

[6] Fernández-Bertos, M., Simons, S.J.R., Hills, C.D. and Carey, P.J. (2004) A Review of Accelerated Carbonation Technology in the Treatment of Cement-Based Materials and Sequestration of $\mathrm{CO}_{2}$. Journal of Hazardous Materials, 112, 193-205.

https://doi.org/10.1016/j.jhazmat.2004.04.019

[7] Chimenos, J.M., Fernandez, A.I., Miralles, L., Segarra, M. and Espiell, F. (2003) Short-Term Natural Weathering of MSWI Bottom Ash as a Function of Particle Size. Waste Management, 23, 887-895.

https://doi.org/10.1016/S0956-053X(03)00074-6

[8] Freyssinet, P., Piantone, P., Azaroual, M., Itard, Y., Clozel-Leloup, B., Guyonnet, D. and Baubron, J.C. (2002) Chemical Changes and Leachate Mass Balance of Municipal Solid Waste Bottom Ash Submitted to Weathering. Waste Management, 22, 159-172. https://doi.org/10.1016/S0956-053X(01)00065-4

[9] Piantonea, P., Bodénana, F. and Chatelet-Snidarob, L. (2004) Mineralogical Study of Secondary Mineral Phases from Weathered MSWI Bottom Ash: Implications for the Modelling and Trapping of Heavy Metals. Applied Geochemistry, 19, 18911904. https://doi.org/10.1016/j.apgeochem.2004.05.006

[10] Polettini, A. and Pomi, R. (2004) The Leaching Behavior of Incinerator Bottom Ash as Affected by Accelerated Ageing. Journal of Hazardous Materials, 113, 209-215. https://doi.org/10.1016/j.jhazmat.2004.06.009

[11] Speiser, C., Baumann, T. and Niessner, R. (2000) Morphological and Chemical Characterization of Calcium Hydrate Phases Formed in Alteration Processes of Deposited Municipal Solid Waste Incinerator Bottom Ash. Environmental Science \& Technology, 34, 5030-5037. http://pubs.acs.org/doi/abs/10.1021/es990739c https://doi.org/10.1021/es990739c

[12] Ritzkowski, M. and Stegmann, R. (2013) Landfill Aeration within the Scope of Post-Closure Care and Its Completion. Waste Management, 33, 2074-2082. https://doi.org/10.1016/j.wasman.2013.02.004

[13] Bou-Zeid, E. and El-Fadel, E. (2004) Parametric Sensitivity Analysis of Leachate Transport Simulations at Landfills. Waste Management, 24, 681-689. https://doi.org/10.1016/j.wasman.2004.03.004

[14] Imhoff, P.T., Reinhart, D.R., Englund, M., Gue'rin, R., Gawande, N., Han, B., Jonnalagadda, S., Townsend, T.G. and Yazdani, R. (2007) Review of State of the Art Methods for Measuring Water in Landfills. Waste Management, 27, 729-745. https://doi.org/10.1016/j.wasman.2006.03.024

[15] Rosqvist, H. and Destouni, G. (2000) Solute Transport through Preferential Pathways in Municipal Solid Waste. Journal of Contaminant Hydrology, 46, 39-60. https://doi.org/10.1016/S0169-7722(00)00127-3

[16] Öncü, G., Reiser, M. and Kranert, M. (2012) Aerobic in Situ Stabilization of Landfill Konstanz Dorfweiher: Leachate Quality after 1 Year of Operation. Waste Manage- 
ment, 32, 2374-2384. https://doi.org/10.1016/j.wasman.2012.07.005

[17] Cossu, R. and Lai, T. (2012) Washing of Waste Prior to Landfilling. Waste Management, 32, 869-878. https://doi.org/10.1016/j.wasman.2011.12.005

Submit or recommend next manuscript to SCIRP and we will provide best service for you:

Accepting pre-submission inquiries through Email, Facebook, LinkedIn, Twitter, etc. A wide selection of journals (inclusive of 9 subjects, more than 200 journals)

Providing 24-hour high-quality service

User-friendly online submission system

Fair and swift peer-review system

Efficient typesetting and proofreading procedure

Display of the result of downloads and visits, as well as the number of cited articles Maximum dissemination of your research work

Submit your manuscript at: http://papersubmission.scirp.org/

Or contact gep@scirp.org 